\title{
Impact of eating disorders on quality of life of women during the perimenopausal period
}

\author{
Wpływ zaburzeń odżywiania na jakość życia kobiet w okresie okołomenopauzalnym
}

\author{
Artur Ostrzyżek \\ Zakład Pedagogiki Terapeutycznej, Instytut Nauk Pedagogicznych, Uniwersytet Jana Kochanowskiego w Kielcach \\ kierownik Zakładu: dr hab. Marta Woldańska-Okońska, prof. UJK
}

Przegląd Menopauzalny 2013; 4: 343-346

\section{Summary}

Eating disorders pose a serious medical, clinical and social problem. In the recent years cases of the lack of appetite are more often diagnosed in reference to middle-aged and elderly women. A situation like this may result from an existing disease process, a continuation of experiencing such problems in the past, and also a reflection of the trends being created by the modern media advocating the need for keeping a woman's physical attractiveness in her late adulthood. It happens more and more often that the effort to reduce weight achieve a slimmer look is taken by women in their 50s, and even 60s. There is also an existing view that eating disorders among elderly women appear in a close connection to psychical disorders. Many women perceive menopause as a loss and a sign of an oncoming old age, thus they are focused mainly on negative emotions in this period of life. On the basis of depression-like disorders, there appear problems with controlling and maintaining the body mass. Although the scale of the phenomenon has still a limited range and character, its significant impact on life quality of women's population in the menopausal period justifies the execution of the current review of the subject literature in this matter.

Key words: menopause, eating disorders, quality of life.

\section{Streszczenie}

Zaburzenia odżywiania stanowią istotny problem medyczny, kliniczny i społeczny. W ostatnich latach przypadki występowania zaburzeń łaknienia coraz częściej diagnozuje się u kobiet w średnim i starszym wieku. Sytuacja taka może być wynikiem istniejącego procesu chorobowego, kontynuacją doświadczania problemów tego typu w przeszłości, jak również odzwierciedleniem kreowanych przez współczesne media trendów, głoszących potrzebę zachowania atrakcyjności fizycznej przez kobiety w późnej dojrzałości. Coraz częściej zdarza się, że wysiłek obniżenia wagi i uzyskania szczupłego wyglądu podejmują kobiety po 50., a nawet 60. roku życia. Istnieje również pogląd, że zaburzenia odżywiania u kobiet w starszym wieku pojawiają się w ścisłym związku z innymi zaburzeniami psychicznymi. Wiele kobiet postrzega menopauzę w kategoriach straty i zapowiedzi bliskiej starości, dlatego skupia się w tym okresie życia głównie na negatywnych emocjach. Na podłożu zaburzeń o typie depresji pojawiają się problemy z kontrolą i utrzymaniem masy ciała. Jakkolwiek skala zjawiska ma wciąż ograniczony zasięg i charakter, jej znaczący wpływ na jakość życia populacji kobiet w okresie menopauzalnym uzasadnia dokonanie aktualnego przeglądu literatury przedmiotu w tym zakresie.

Słowa kluczowe: menopauza, zaburzenia odżywiania, jakość życia.

\section{Introduction}

The progress of medicine and medical sciences observed mainly in the last century has driven civilizational standards and human life towards more healthconscious attitudes, contributing primarily to a marked extension of human lifespan. Not so long ago, living to an old age was rare, while the average life expectancy in the $19^{\text {th }}$ century did not exceed 50 years.

There are sources indicating that during the period of the Roman Empire women typically experienced the cessation of their menstrual periods under 30 years 
of age. In the Middle Ages, women's monthly periods usually stopped at around 33 years of age, whereas at the turn of the $20^{\text {th }}$ century the time varied between 38 and 41 years of age. The majority of women did not live long enough to enter the climacteric period [1].

Nowadays, an earlier onset of puberty is not associated with an earlier menopause. In fact, there is a trend for the menopause to be delayed.

The average age of the menopause in Europe is between 45 and 55 years. It is interesting to note, though, that the length of the reproductive cycle in humans is not adequately long compared to other primates [2].

Eating disorders (EDs) represent a major medical, clinical and social problem. The fundamental predictor of eating disorders is the female sex [3].

Recent years have seen an increase in the number of appetite cases diagnosed among middle-aged and elderly women [4]. Eating disorders are routinely differentiated on the basis of the ICD-10 (International Classification of Diseases $-10^{\text {th }}$ Revision) and the DSM-IV (Diagnostic and Statistical Manual of Mental Disorders $4^{\text {th }}$ Edition) published by the American Psychiatric Association. Both classification systems distinguish the following categories of eating disorders:

1) anorexia nervosa (AN),

2) bulimia nervosa (BN),

3) atypical eating disorders (AEDs).

The DSM-IV additionally identifies:

1) binge eating disorder (BED),

2) night eating syndrome (NES).

It also seems justified to expand the above range of eating dysfunctions by adding obesity together with other hyperalimentation and malnutrition syndromes listed in the ICD-10 Chapter IV: Endocrine, nutritional and metabolic diseases.

The reasons for the development of eating disorders among women in the midlife age group are complex. They seem to be attributable mainly to psychological and sociocultural factors, and causes collectively referred to as midlife developmental challenges, of which the most important remains the menopausal status [5]. Growing requirements with regard to women past 40 years of age, longer period of professional activity and widespread body dissatisfaction caused by the drive for thinness and physical attractiveness promoted by the media result in a state of constant emotional tension [6]. Most women consider the menopause in the categories of loss and approach of old age, focusing exclusively on negative emotions associated with this transition period. Feeling less feminine and less attractive, women focus their entire attention on the physical signs of ageing. The effort to lose weight and regain a slim figure is often undertaken by women in their 50s or even 60s [7].

Some researchers argue that eating disorders occur more commonly in women who suffered from anorexia nervosa or atypical (often undiagnosed and untreated) eating disorders during their adolescence. Rabe-Jabłońska claims that eating disorders in elderly women typically emerge in conjunction with other mental disorders, primarily of the depressive spectrum, or mask them [8].

Depressive disorders requiring therapy are diagnosed in $20-30 \%$ of perimenopausal women, while the risk of depression is higher among women who are transitioning through menopause or who are immediately postmenopausal rather than premenopausal [9].

An increase in negative symptoms accompanying the menopause is often positively correlated with the negative attitude exhibited by women towards this period of life, as outlined above [10].

These disorders are a foundation that underlies problems with maintaining and controlling body weight which, in turn, have a direct impact on the level of life satisfaction and its quality.

\section{MENQOL (menopause-specific quality of life) predictors}

The quality of life continues to be the topic of many reports. However, there is no agreement either as to the definition or even the more general concept of quality of life. Researchers specializing in the topic, however, are apt to agree that the quality of life has its specific physical, mental and social dimensions - and that it is amenable to assessment in both objective and subjective terms. The World Health Organization (WHO) defines the quality of life (QOL) as an individual's perception of their position in life in the context of the culture and value systems in which they live, and in relation to their goals, expectations, standards and concerns [11]. The main components of menopause-specific quality of life (MENQOL) are recognized as comprising: age, menopausal stage, number of children, level of education, employment status and BMI.

A number of studies have shown that the menopause has an adverse effect on all QOL aspects [12, 13]. With regard to the population of perimenopausal women, an emphasis is placed on the predictive role of critical life events for health and global QOL assessment [14].

\section{Anorexia and bulimia}

Most of the available publications address the topic of anorexia and bulimia in relation to children and adolescents.

Although the two conditions appear in increasingly younger age groups nowadays, there has been a significant parallel rise in the number of cases diagnosed among older adults. In the healthy female population, $10 \%$ of EDs develop after the age of 25 years [15].

Prolonged eating disorders - including extreme malnutrition which is sometimes associated with anorexia 
- may induce amenorrhoea and premature menopause even in very young women [16].

It is often argued that eating disorders are a metaphorical means of expressing emotions and deprivation of needs among afflicted patients. Among mature women, mental deficits developing with age may be an effect of critical life events which occurred during the period of personality formation. Individuals who were neglected in childhood and had a poor relationship with their parents are likely to be under a greater risk of deficit of social interactions later in life. In each of the situations reduced quality of life is a direct and important consequence of the history of alimentary dysfunctions.

Studies by Patrick et al. investigating eating disorders in a population of women aged 30-49 years have demonstrated a significantly increased risk of ED development in the perimenopausal period [17].

In the study by Bamford et al., predictors of low quality of life in the study group of women were found to be severity of the eating disorders and the BMI, whereas - contrary to clinical expectations - the duration of the disease did not reveal itself as a major predictive factor in this respect [18].

Jafary et al. assessed the QOL in a representative group of women aged 45-55 years in a search for correlations existing between their life satisfaction and the sense of meaning of life, body satisfaction, global life evaluation as well as assessment of self-efficacy and health. Self-efficacy, body image and health evaluation were found to be predictors of the level of quality of life in the group analyzed [19].

Marcus et al. examined a group of 589 perimenopausal women, demonstrating that in $29.3 \%$ of subjects the main factor triggering disordered eating was related to their parents' negative eating patterns [20].

Zerbe notes the marked progress that has been achieved in clinical practice in terms of growing number of cases of eating disorders (bulimia and anorexia types) diagnosed in midlife. At the same time, however, attention is drawn to potential diagnostic difficulties involved in this category of diseases and to the need to perform additional psychiatric assessment and take into account other relevant medical factors [21].

\section{Obesity}

The number of people suffering from obesity has been rising sharply, and the condition is perceived as an epidemic of the $21^{\text {st }}$ century. While obesity is not essentially a problem in itself, it is a factor conducive to the development of a number of diseases including heart conditions, brain strokes, diabetes type 2, hypertension or cancer [22].

WHO data show that in 2008 a total of 1.5 billion people worldwide were overweight. The group comprised 200 million men and nearly 300 million women suffering from obesity. According to forecasts developed by WHO experts, the number will rise to 2.3 billion people by 2015 [23].

Overweight and obesity occur the most frequently in perimenopausal women [24]. The menopause is associated with an unfavourable lipid profile, i.e. low levels of alpha lipoprotein (HDL) cholesterol and high triglyceride (TG) concentrations, accumulation of visceral adipose tissue and insulin resistance. In premenopausal women and women on hormone replacement therapy (HRT) fatty tissue deposits chiefly under the skin, in the femorogluteal and mammary regions. After the menopause, however, changes in the levels of sex steroids lead to the visceral redistribution of adipose tissue. Multiple studies have demonstrated that subcutaneous fatty tissue differs from intra-abdominal fat in terms of metabolic activity.

During the premenopausal period, subcutaneous adipocytes - which show increased sensitivity to insulin - inhibit the process of lipolysis in this area, mediating their hypertrophy. Postmenopausally, the weight of visceral adipose tissue may increase by up to $50 \%$. Until recently, obesity was considered a protective factor reducing the risk of osteoporosis [25].

New reports, however, show that abdominal obesity may actually be an independent risk factor for bone mass loss and development of osteoporosis [26].

Fallahzadeh investigated a group of 480 women aged between 40 and 65 years, of which $46.4 \%$ were overweight and $19.7 \%$ were obese, concluding that a significant decrease of the quality of life in the study group was correlated with younger age and lower level of education [27].

The finding may be related to the view presented in literature that even though women tend to be dissatisfied with their body image throughout all their lives, their level of self-esteem in this respect may increase at an older age [28].

Lee et al. sought to establish the link between depressive symptoms and adipose tissue location in a population of premenopausal overweight women who exhibited no signs of eating disorders. The authors argue that the accumulation of visceral adipose tissue (VAT) may have a prognostic significance for the development of depression-type disorders or secondary coronary insufficiency [29].

Alvarez-Blasco et al. compared health-related quality of life (HR-QoL) in a group of premenopausal women suffering from obesity and polycystic ovary syndrome (PCOS). Findings of the study indicate a stronger predicative impact of obesity on the quality of life in the study group [30]. Furthermore, women with higher BMI scores had a significantly increased frequency of vasomotor symptoms [31].

Goulet et al. examined relationships between health behaviours and food and drink consumption in healthy postmenopausal women (age 56.8 [SD 4.4] years). The au- 
thors stress that even though dietary counselling remains the key element of weight control, interventional activities aimed at modifying eating habits may have a positive effect on food choices, which in turn favourably affects regulation of energy balance and body weight [32].

\section{References}

1. Jakowicki J. Współczesne poglądy na zjawiska hormonalne i morfologiczne okresu przedmenopauzalnego i przekwitania. In: Jakowicki J (ed.). Klimakterium. Problemy kliniczne. Hormonalna terapia zastępcza. Folium, Lublin 1995.

2. Kachel AF, Premo LS, Hublin JJ. Modeling the effects of weaning age on length of female reproductive period: implications for the evolution of human life history. Am J Hum Biol 2011; 23: 479-87.

3. Striegel-Moore RH, Bulik CM. Risk factors for eating disorders. Am Psychol 2007; 62: 181-98.

4. Midlarsky E, Nitzburg G. Eating disorders in middle-aged woman. J Gen Psychol 2008; 135: 393-407.

5. Slevec JH, Tiggemann M. Predictors of body dissatisfaction and disordered eating in middle-aged women. Clin Psychol Rev 2011; 31: 515-24.

6. Holm-Denoma JM, Richey JA, Joiner TE. The latent structure of dietary restraint, body dissatisfaction, and drive for thinness: a series of taxometric analyses. Psychol Assess 2010; 22: 788-97.

7. Rush EC, Chandu V, Plank LD. Reduction of abdominal fat and chronic disease factors by lifestyle change in migrant Asian Indians older than 50 years. Asia Pac J Clin Nutr 2007; 16: 671-6.

8. Rabe-Jabłońska J. Jadłowstręt psychiczny u dorosłych kobiet. Psychiatr Pol 2003; 37: 29-37.

9. Bromberger JT, Krawitz HM, Chang YF et al. Major depression during and after the menopausal transition: Study of Women's Health Across the Nation (SWAN). Psychol Med 2011; 41: 1879-88.

10. Ayers B, Forshaw M, Hunter MS. The impact of attitudes towards the menopause on woman's symptom experience: a systematic review. Maturitas 2010; 65: 28-36.

11. WHOQOL Group. What Quality of Life? World Health Forum 1996; 17: 354-6.

12. Blumel JE, Castelo-Branco C, Binfa L et al. Quality of life after the menopause: a population study. Maturitas 2000; 34: 17-23.

13. Lai JN, Chen HJ, Chen CM et al. Quality of life and climacteric complaints amongst women seeking medical advice in Taiwan: assessment using the WHOQOL-BREF questionnaire. Climacteric 2006; 9: 119-28.

14. Alexander JL, Dennerstein L, Woods NF. Role of stressful life events and menopausal stage in wellbeing and health. Expert Rev Neurother 2007; 7: S93-113.
15. Favaro A, Caregaro L, Tenconi E. Time trends in age at onset of anorexia nervosa and bulimia nervosa. J Clin Psychiatry 2009; 70: 1715-21.

16. Abraham SF, Pettigrew B, Boyd C et al. Predictors of functional and exercise amenorrhoea among eating and exercise disordered patients. Hum Reprod 2006; 21: 257-61.

17. Patrick JH, Stahl ST. Understanding disordered eating at midlife and late life. J Gen Psychol 2009; 136: 5-20.

18. Bamford B, Sly R. Exploring quality of life in the eating disorders. Eur Eat Disord Rev 2010; 18: 147-53.

19. Jafary F, Farahbakhsh K, Shafiabadi A et al. Quality of life and menopause: Developing a theoretical model based on meaning in life, selfefficacy beliefs, and body image. Aging Ment Health 2011; 15: 630-7.

20. Marcus MD, Bromberger JT, Wei HL et al. Prevalence and selected correlates of eating disorder symptoms among a multiethnic community sample of midlife women. Ann Behav Med 2007; 33: 269-77.

21. Zerbe KJ. Eating disorders in midlife and late life: A neglected problem. Prim Psychiatry 2003; 10: 76-8.

22. Haslam DW, James WP. Obesity. Lancet 2005; 366: 1197-1209.

23. World Health Organization 2011. Obesity and overweight. Fact sheet №311.

24. Teede HJ, Lombard C, Deeks AA. Obesity, metabolic complications and the menopause: An opportunity for prevention. Climacteric 2010; 13: 203-9.

25. Vermeulen A. Environment, human reproduction, menopause and andropause. Environ Health Perspect 1993; 101: 91-100.

26. Bredella MA, Torriani M, Ghomi RH et al. Determinants of bone mineral density in obese premenopausal women. Bone 2011; 48: 748-54.

27. Fallahzadeh H. Quality of life after menopause. Qual Life Res 2010; 19: 813-9.

28. Peat CM, Peyerl NL, Muehlenkamp JJ. Body image and eating disorders in older adults: a review. J Gen Psychol 2008; 135: 343-58.

29. Lee ES, Kim YH, Beck SH et al. Depressive mood and abdominal fat distribution in overweight premenopausal women. Obes Res 2005; 13: 320-5.

30. Alvarez-Blasco F, Lugue-Ramirez M, Escobar-Morreale HF. Obesity impairs general health-related quality of life (HR-QoL) in premenopausal women to a greater extent than polycystic ovary syndrome (PCOS). Clin Endocrinol 2010; 73: 595-601.

31. Gold EB, Block G, Crawford S et al. Lifestyle and demographic factors in relation to vasomotor symptoms: Baseline results from the Study of Women's Health Across the Nation. Am J Epidemiol 2004; 159: 1189-99.

32. Goulet J, Provencher V, Piche ME et al. Relationship between eating behaviours and food and drink consumption in healthy postmenopausal women in a real-life context. Brit J Nutr 2008; 100: 910-7. 